\title{
Dental anomalies in Didelphis albiventris (Mammalia, Marsupialia, Didelphidae) from Argentina, Brazil and Uruguay
}

\author{
M. Amelia Chemisquy’ \& Gabriel M. Martin²
}

\begin{abstract}
1. Centro Regional de Investigaciones Científicas y Transferencia Tecnológica de La Rioja (CRILAR), Provincia de La Rioja, UNLaR, UNCa, SEGEMAR, CONICET, Entre Ríos y Mendoza s.n., CP 5301, Anillaco, La Rioja, Argentina. (amelych80@gmail.com)

2. Centro de Investigación Esquel de Montaña y Estepa Patagónicas (CIEMEP), UNPSJB, CONICET, Roca 780, CP 9200, Esquel, Chubut, Argentina. (gmartin_ar@yahoo.com)
\end{abstract}

ABSTRACT. Dental anomalies have been investigated and reported for most orders of mammals, including marsupials. Previous works in Didelphis albiventris Lund, 1840 only described one kind of malformation or just a few observations from some collections, thus the type and presence of anomalies for this species was underestimated. The aim of this contribution is to describe and analyze several dental anomalies found in specimens of Didelphis albiventris from Argentina, Uruguay and Brazil. Dental anomalies were classified in three categories: supernumerary or missing teeth, morphological anomalies in size and shape, and teeth in unusual positions. We found 32 individuals of $D$. albiventris with anomalies out of 393 analyzed specimens $(8.14 \%)$, some specimens with more than one anomaly. A similar proportion of specimens from Argentina and Uruguay presented anomalies, while in specimens from Brazil anomalies were less common. Anomalies were more commonly found in the upper toothrow and in molars, being supernumerary teeth and molars with unusual crown-shape the most common ones. The percentage of specimens with anomalies found for D. albiventris is higher than previously reported for the species, and other Didelphimorphia. Inbreeding and limited gene flow do not appear as possible explanations for the elevated percentage of anomalies, especially due to the ecological characteristics of Didelphis albiventris. Developmental instability and fluctuating asymmetry could be some of the causes for the anomalies found in this species, mostly since the habitat used by D. albiventris tends to be unstable and disturbed. Dental anomalies were mostly found in areas of the toothrow where occlusion is relaxed or does not prevent teeth from interlocking during mastication, and consequently have no functional value.

KEYWORDS. Anomalous teeth, developmental instability, supernumerary teeth, white-eared opossum.

RESUMEN. Anomalías en la dentición de Didelphis albiventris (Didelphidae). Las anomalías en la dentición se han estudiado en la mayoría de los órdenes de mamíferos, incluyendo marsupiales. Trabajos anteriores en Didelphis albiventris Lund, 1840 analizaron solamente un tipo de malformación, o un número acotado de ejemplares, subestimando así el tipo y número de anomalías para esta especie. El objetivo de este trabajo es describir y analizar varias anomalías dentales encontradas en muestras de Didelphis albiventris provenientes de Argentina, Uruguay y Brasil. Las anomalías se clasificaron en tres categorías: dientes supernumerarios o ausentes; anomalías morfológicas de tamaño y forma; y dientes en posiciones inusuales. De los 393 ejemplares analizados, encontramos 32 individuos de $D$. albiventris con anomalías (8,14\%), algunos de los cuales presentaron más de una anomalía. Una proporción similar de especímenes de Argentina y Uruguay presentó anomalías, mientras que en la muestra de Brasil las anomalías fueron menos comunes. Las anomalías se encontraron más frecuentemente en la serie dentaria superior y en los molares, siendo los molares supernumerarios y los dientes con malformaciones en la corona las más comunes. El porcentaje de muestras con anomalías encontrado para $D$. albiventris es mayor que los reportados previamente para la especie y para otros Didelphimorphia. La endogamia y el flujo génico limitado no parecen ser posibles explicaciones para el elevado porcentaje de anomalías, especialmente debido a las características ecológicas de Didelphis albiventris. La inestabilidad en el desarrollo y la asimetría fluctuante podrían ser algunas de las causas de las anomalías, sobre todo debido a que el hábitat utilizado por D. albiventris tiende a ser inestable y encontrarse modificado. Las anomalías dentales se encontraron, principalmente, en las áreas de la serie dental donde la oclusión es relajada o no evita que los dientes ocluyan durante la masticación, y por lo tanto no tienen ningún valor funcional.

PALABRAS-CLAVE. Dientes anómalos, inestabilidad en el desarrollo, dientes supernumerarios, comadreja overa.

The white-eared opossum, Didelphis albiventris Lund, 1840, is a widely distributed species in southern South America, occurring from northeastern and central Brazil, Paraguay and central Bolivia, to Uruguay and the Argentine provinces of Neuquén and Río Negro (Massoia \& Lartigau, 1995; Massoia et al., 2000; Cerqueira \& Tribe, 2008; Carrera \& Udrizar SaUthier, 2014). It is a species that tolerates disturbed and fragmented habitats, including cultivated lands and large cities, exploiting human habitation for food resources (SMith, 2007; CosTa et al., 2015). Although it prefers areas in close proximity to water and trees, the species can also be found in the Dry Chaco and the Patagonian Steppe (FlORES, 2006; SMITH, 2007).

As other Didelphis species, D. albiventris has a generalized diet, including all sorts of items, such as a wide variety of vertebrates, eggs, carrion, invertebrates, nectar and fruits (VieIRA \& Astúa De Moraes, 2003). This lack of specialization is reflected by their generalized skull and tooth 
morphology, and skull musculature (LEE \& COCKBURN, 1987; VIEIRA \& Astúa De Moraes, 2003; ChemisQuy et al., 2015).

Didelphids preserve the primitive marsupial dental formula, with five upper and four lower incisors, one canine, three premolars and four tribosphenic molars, being the upper fourth molar reduced, and only one deciduous functional tooth, the third premolar (UNGAR, 2010). Individuals of $D$. albiventris complete their dentition by the age of 10 months approximately (TyNdALE-Biscoe \& MaCKenzIE, 1976). However, teeth may vary in number, size, shape and position within the same species, and these changes are considered as dental anomalies when they are conspicuous and unusual (Miles \& Grigson, 1990).

Dental anomalies have been investigated and reported for most orders of mammals (e.g. WoLSAN, 1984; Miles \& Grigson, 1990; MCAfee, 2015; Drehmer et al., 2015; GonZÁLEZ- RuIZ et al., 2015), including marsupials (e.g., Archer, 1975; Miles \& Grigson, 1990; Astúa DE Moraes et al., 2001; Martin, 2007, 2013). Even for Didelphis albiventris, previous works reported evidence of supernumerary teeth (GONZÁlez, 2000; Astúa DE MoRAES et al., 2001), as well as other abnormalities (MILES \& GRIGSON, 1990; as D. azarae Temminck, 1824). However, these previous reports on $D$. albiventris only represent one kind of malformation (i.e., supernumerary molars, GONZÁLEZ, 2000; AstúA DE MoRAes et al., 2001) or just a few observations from some collections (MiLES \& GRIGSON, 1990; GONZÁLEZ, 2000), thus the type and presence of anomalies for this species was underestimated.

The aim of this contribution was to describe and analyze several dental anomalies found in specimens of Didelphis albiventris from Argentina, Uruguay and Brazil, discussing their possible causes and their morphofunctional consequences. Results were compared to those described previously for other South American marsupials, as well as with results from the observation of some specimens of $D$. aurita Wied-Neuwied, 1826 and D. marsupialis Linnaeus, 1758 from Brazil.

\section{MATERIALS AND METHODS}

We analyzed 393 specimens of Didelphis albiventris from the following collections: División Mastozoología, Museo Argentino de Ciencias Naturales "Bernardino Rivadavia", Ciudad Autónoma de Buenos Aires, Argentina (MACN); Fundación de Historia Natural Félix de Azara, Ciudad Autónoma de Buenos Aires, Argentina (CFA); Sección Mastozoología, Museo de La Plata, Argentina (MLPMa); Museo Provincial de Ciencias Naturales "Florentino Ameghino", Santa Fe, Argentina (MSF); Colección de Mamíferos del Centro Nacional Patagónico, Puerto Madryn, Argentina (CNP); Colección de Mamíferos del Centro Regional de Investigaciones Científicas y Transferencia Tecnológica, Anillaco, Argentina (CRILAR-Ma); Museo Nacional de Historia Natural, Montevideo, Uruguay (MNHN); Colección de Vertebrados, Facultad de Ciencias, Universidad de la República, Montevideo, Uruguay (ZVC);
Museu de Zoologia, Universidade de São Paulo, Brazil (MZUSP); American Museum of Natural History, New York, USA (AMNH); Naturhistorisches Museum Wien, Vienna, Austria (NMW). Collection number, sex and locality for studied specimens with anomalies are listed in Appendix 1. For the analysis, we only included adult specimens (i.e., those with fully erupted molars in their final position).

Tooth morphology nomenclature follows REIG et al. (1987). Upper and lower dentitions are indicated by a numerical superscript and subscript, respectively (e.g., $\mathrm{M}^{4}$ refers to the fourth upper molar, and $\mathrm{M}_{4}$ refers to the lower one), while incisors are indicated by the letter I, canines by $\mathrm{C}$, premolars by $\mathrm{P}$, molars by $\mathrm{M}$, and the deciduous premolar by $\mathrm{dP}$.

Dental anomalies were classified in three categories, modified from MiLes \& Grigson (1990) and MARTIN (2007): (1) supernumerary or missing teeth (loss not produced by a physical disturbance). Supernumerary teeth can have the same shape as the teeth of the normal series (though not the same size), they can be haplodont or peg-like, or they can be tuberculated, with complex crowns. There are also differences in the position of supernumerary teeth, since they can be placed within the toothrow or at the end, or in places where the teeth are adjacent to the toothrow. The causes of both placements will be discussed below. (2) Morphological anomalies in size and shape. In this case, we refer to anomalies in teeth of the normal series, not of supernumerary teeth (e.g., a missing protocone, a double cusped premolar). (3) Teeth in unusual positions. Here we refer to the position of a tooth within the normal series (e.g., a flipped molar, a transversely oriented premolar).

\section{RESULTS}

We found 32 individuals of $D$. albiventris with anomalies, out of 393 analyzed specimens (8.14\%; Tab. I). Six of those 32 individuals showed more than one anomaly. If we divide the sample by country, we found a similar proportion of specimens with anomalies from Argentina and Uruguay $(\sim 11 \%)$, while only $3.5 \%$ of the specimens from Brazil showed some kind of anomaly (Tab. I; Fig. 1). The sex of only 17 specimens was available; of those 10 were females, and 7 were males. Anomalies were more commonly found in the upper toothrow $(n=25 ; 69.44 \%)$, with only 11 anomalies (30.56\%) found in the lower toothrow (Tab. II).

Anomalies were more frequently found in molars $(61.11 \%)$, being supernumerary teeth and molars with unusual crown shape the most common ones (Tab. II). We found $36.11 \%$ of anomalies in premolars, in which supernumerary teeth was the most common anomaly (Tab. II). We only found two cases of anomalies in the incisors of a single specimen (2.78\%; Tab. II).

Supernumerary teeth were found in 19 specimens, one with supernumerary molars and premolars (Tab. II). The most common supernumerary teeth were found at the end of the toothrow (11 $\left.\mathrm{M}^{5}, 1 \mathrm{M}_{5}\right)$, while six specimens showed extra premolars. Missing teeth were not commonly 
Tab. I. Specimens of Didelphis albiventris Lund, 1840, analyzed and percentage of anomalies for the complete sample and for each country.

\begin{tabular}{lccc}
\hline & Argentina & Brazil & Uruguay \\
\hline Specimens analyzed & 148 & 174 & 71 \\
Specimens with anomalies & 18 & 6 & 8 \\
Percentage of specimens with anomalies & 12.16 & 3.45 & 32 \\
\hline
\end{tabular}

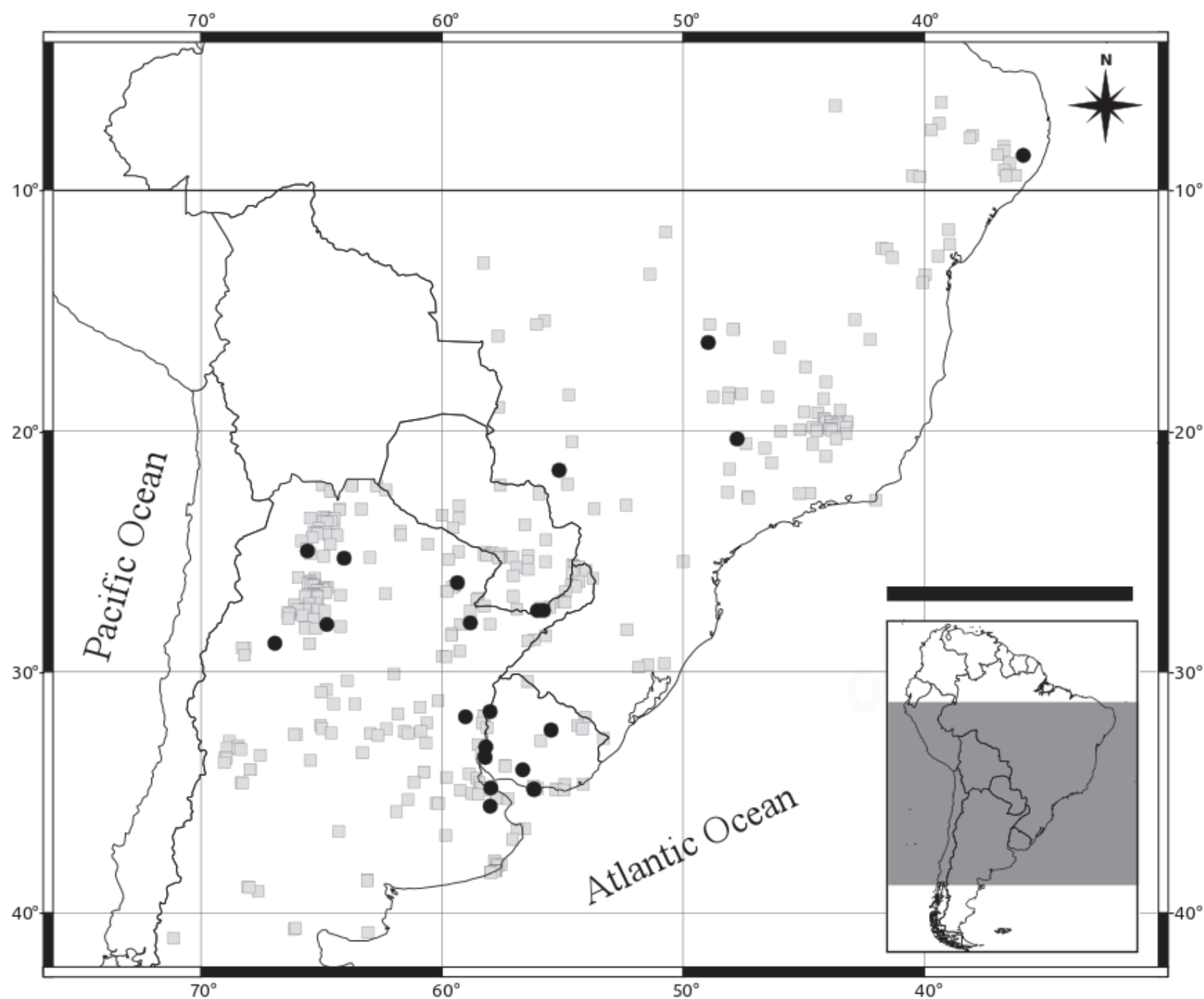

Fig. 1. Map with distribution of the analyzed specimens of Didelphis albiventris Lund, 1840 (grey squares), and distribution of the specimens with dental anomalies (black circles).

found, with only specimen AMNH 132983 lacking a right $M_{1}$. This specimen has no alveoli for this tooth, showing the molar probably never erupted, or the alveoli closed due to unknown reasons. No supernumerary or missing incisors and/or canines were found in our sample.

Four specimens showed extra molars posterior to $\mathrm{M}^{4}$, which resemble regular molars in shape but are generally smaller in size. Specimen CFA 3235 has an extra molar on each side of the upper toothrow, which have the same shape as $\mathrm{M}^{4}$ but are smaller in size (Fig. 2). Specimen MNHN 2544 has one small extra molar on the right upper toothrow, similar in shape to $\mathrm{M}^{4}$, while a missing extra-tooth is inferred on the left side by an open alveolus. Specimen MACN 36753 has an extra molar on the left upper toothrow, labial to $\mathrm{M}^{4}$, which resembles $\mathrm{M}^{1}$ in size (Fig. 3). The presence of this extra molar makes $\mathrm{M}^{4}$ to be lingually oriented. Specimen MACN 24174 has a supernumerary molar at the end of the left upper toothrow, which resembles a $\mathrm{M}^{4}$ in shape but is rotated $90^{\circ}$ counter-clockwise (Fig. 4). Four individuals had supernumerary molars which were reduced in size, and had abnormal crown shapes. Specimen MACN 25.23 has one extra molar on the right upper toothrow, placed between $\mathrm{M}^{3}$ and $\mathrm{M}^{4}$, and slightly labially oriented (Fig. 5). Two cusps are clearly present, but it is difficult to identify what they are equivalent to in normal teeth. Specimen ZVC 1167 has one supernumerary molar posterior to each $\mathrm{M}^{4}$, which are small and with an oval crown. The one on the right has two cusps, while the one on the left is slightly larger, and has three cusps. Specimen AMNH 132951 has an extra molar posterior to the right $\mathrm{M}_{4}$, which is still erupting, while specimen MNHN 
Tab. II. Specimens of Didelphis albiventris Lund, 1840 with dental anomalies. Some specimens count in more than one category. Percentages are given in relation to the total number of anomalies. (U): upper dental row, (L) lower dental row, (R) right side; (F) left side. Specimens in bold have symmetric anomalies.

\begin{tabular}{|c|c|c|c|}
\hline Type of anomaly & Incisives & Premolars & Molars \\
\hline \multicolumn{4}{|l|}{ Supernumerary teeth } \\
\hline Missing teeth & & & AMNH 132983(LR) \\
\hline Normal shape & & CNP s.n.(UR) & $\begin{array}{l}\text { MACN 24174(UF) } \\
\text { MACN 36753(UF) } \\
\text { MNHN 2544(U) } \\
\text { CFA 3235(U) }\end{array}$ \\
\hline Tuberculate & & & $\begin{array}{l}\text { MACN 25.23(UR) } \\
\text { ZVC 1167(U) } \\
\text { MNHN 2590(UR) } \\
\text { AMNH 132951(LR) }\end{array}$ \\
\hline Peg-like & & $\begin{array}{l}\text { MACN 24174(LF) } \\
\text { MNHN 3394(LF) } \\
\text { CFA 6041(UF) } \\
\text { AMNH 132984(LR) } \\
\text { CRILAR-Ma NN(UR) }\end{array}$ & $\begin{array}{l}\text { MACN 49.49(UF) } \\
\text { CFA 4510(UR) }\end{array}$ \\
\hline Unknown & & & $\begin{array}{l}\text { MNHN 3964(UF) } \\
\text { MNHN 3961(UF) }\end{array}$ \\
\hline Morphological anomalies & & $\begin{array}{l}\text { MACN 32.184(UF) } \\
\text { MACN 36.734(LR) } \\
\text { MACN 24168(U) } \\
\text { AMNH 132949(U) } \\
\text { CNP s.n.(UF) }\end{array}$ & $\begin{array}{l}\text { MACN 49.49(UF) } \\
\text { MACN 32.184(UF) } \\
\text { ZVC 1285(UR) } \\
\text { CFA 2663(LF) } \\
\text { CFA 10249(UF) } \\
\text { AMNH 132983(LF) } \\
\text { MZUSP 16536(L) }\end{array}$ \\
\hline Unusual position & MACN 24163(LF) & $\begin{array}{l}\text { AMNH 41536(UF) } \\
\text { MNHN 3963(LF) }\end{array}$ & $\begin{array}{l}\text { MZUSP 16536(U) } \\
\text { MZUSP 2996(UR) }\end{array}$ \\
\hline Total number of anomalies & 1 & 13 & 22 \\
\hline Percentage & $2.78 \%$ & $36.11 \%$ & $61.11 \%$ \\
\hline
\end{tabular}

2590 also has an extra molar which is not fully erupted, placed posterior to the right $\mathrm{M}^{4}$ (Fig. 6). Although their shape is not defined yet, they are clearly multi-cuspidate molars.

Two specimens showed peg-like supernumerary molars. Specimen MACN 49.49 has an extra molar between the left $\mathrm{M}^{3}$ and $\mathrm{M}^{4}$, which causes both molars to be malformed and not properly oriented, with the protocone of $\mathrm{M}^{3}$ in contact with the metastylar area of $\mathrm{M}^{2}$, and the protocone of $\mathrm{M}^{4}$ posteriorly directed (instead of strait as in the opposite $\mathrm{M}^{4}$ ) (Fig. 7). Also, due to this malformation $\mathrm{M}^{4}$ has aberrant crown morphology, with a triangular shape not showing the typical antero-posteriorly compressed $\mathrm{M}^{4}$. Specimen CFA 4510 has a small, labially oriented, extra molar placed next to the ectoflexus of the right $\mathrm{M}^{3}$. Finally, both specimens MNHN 3964 and MNHN 3961 have an extra alveolus at the end of the left upper toothrow, implying the presence of an extra molar of unknown shape.

Supernumerary premolars were found in 6 specimens, being peg-like in most cases: next to the left $\mathrm{P}_{3}$ (MACN 24174, MNHN 3394), next to the right $\mathrm{P}^{3}$ (CRILAR-Ma 66), between the right $P_{1}$ and $P_{2}$ (AMNH 132984), and between the upper left canine and $\mathrm{P}^{1}$ (CFA 6041). Specimen CNP s.n. has an extra premolar with the same shape as $\mathrm{P}^{1}$ placed between the right $\mathrm{P}^{1}$ and $\mathrm{P}^{2}$.

Morphological anomalies were most commonly found in molars and premolars $(\mathrm{n}=7, \mathrm{n}=5$, respectively;
Tab. II). Specimen ZVC 1285 has a reduced right $\mathrm{M}^{4}$, which is not only smaller, but also has an oval shape and only two cusps (Fig. 8). Specimen MACN 49.49 has a laterally compressed left $\mathrm{M}^{3}$, with a very reduced metastylar area, an antero-posteriorly compressed protocone, and an abnormal ectoflexus and stylar shelf (Fig. 7). This might be caused by the supernumerary, lingually erupted molar. Specimen MACN 32.184 has an extra alveolus in the left $\mathrm{M}_{1}$. The whole molar is missing, but due to the position of its alveoli we may infer that the molar had an extra root. Specimen CFA 2663 has a reduced left $\mathrm{M}_{4}$, with almost no talonid, while the trigonid is properly developed (Fig. 9). Specimen CFA 10249 has a reduced left $\mathrm{M}^{4}$, with a dorsally oriented metastyle, making the stylar shelf antero-poteriorly compressed (Fig. 10). Specimen AMNH 132983 apparently had a peg-like left $\mathrm{M}_{1}$, which we infer by the shape of the single alveolus (the tooth is missing). Specimen MZUSP 16536 shows both $\mathrm{M}^{4}$ reduced, with a normal shape (regarding the position and number of cusps), but clearly smaller in overall size. As described above, morphologic anomalies in premolars were most common in supernumary teeth (Tab. II). Other morphologic anomalies were found in five specimens: Two individuals (i.e., MACN 24168, AMNH 132949) showed bilateral upper premolars $\left(\mathrm{P}^{2}\right.$ and $\mathrm{P}^{3}$, respectively; Fig. 11) with multiple cusps; three specimens showed anomalies in their roots, which caused abnormalities in crown shape (i.e., 

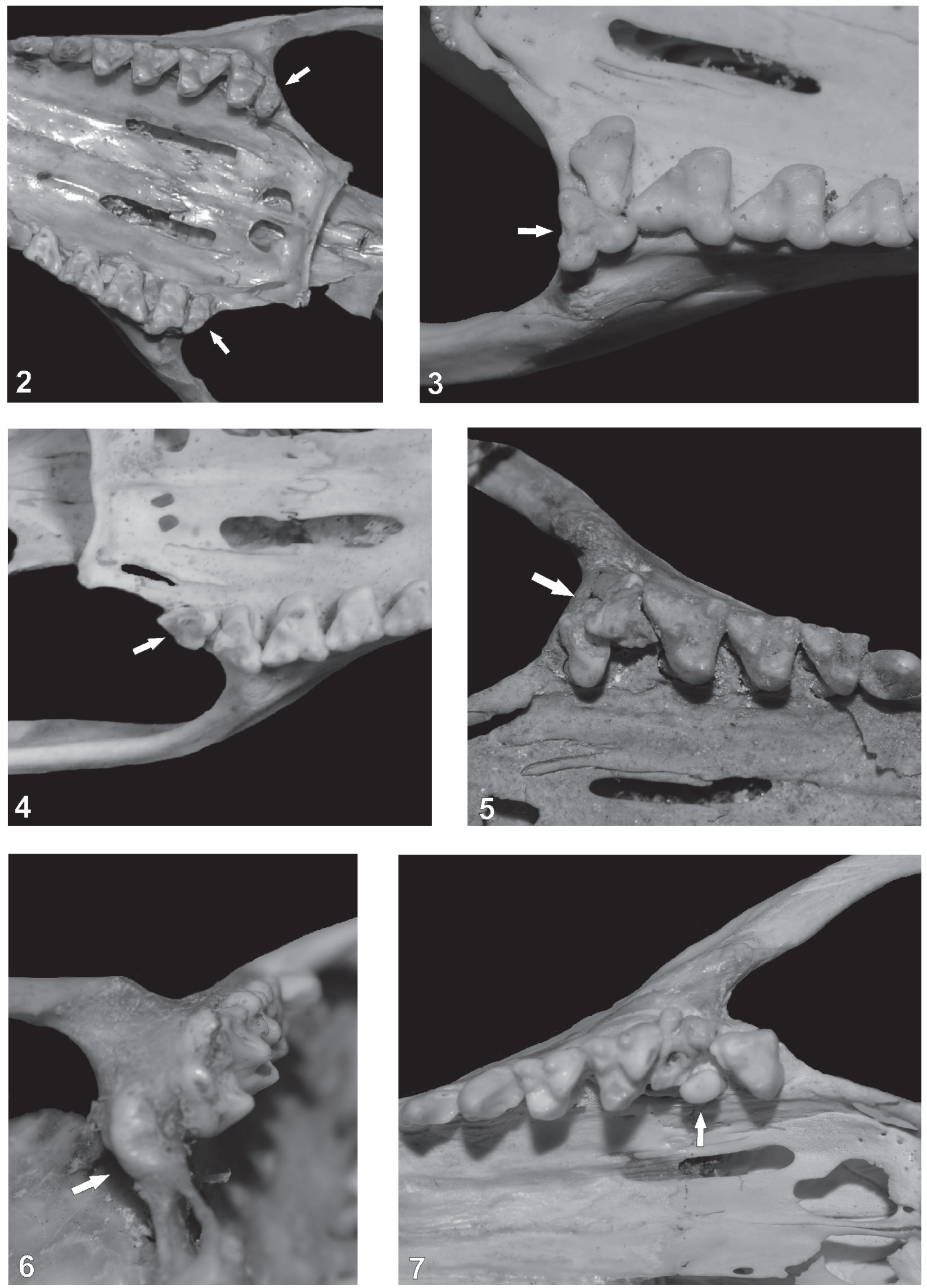

Figs 2-7. Dental anomalies in Didelphis albiventris Lund, 1840: 2, CFA 3235; 3, MACN 36753; 4, MACN 24174; 5, MACN 25.23; 6, MNHN 2590; 7 , MACN 49.49. White arrows indicate the anomaly. See text for details. 

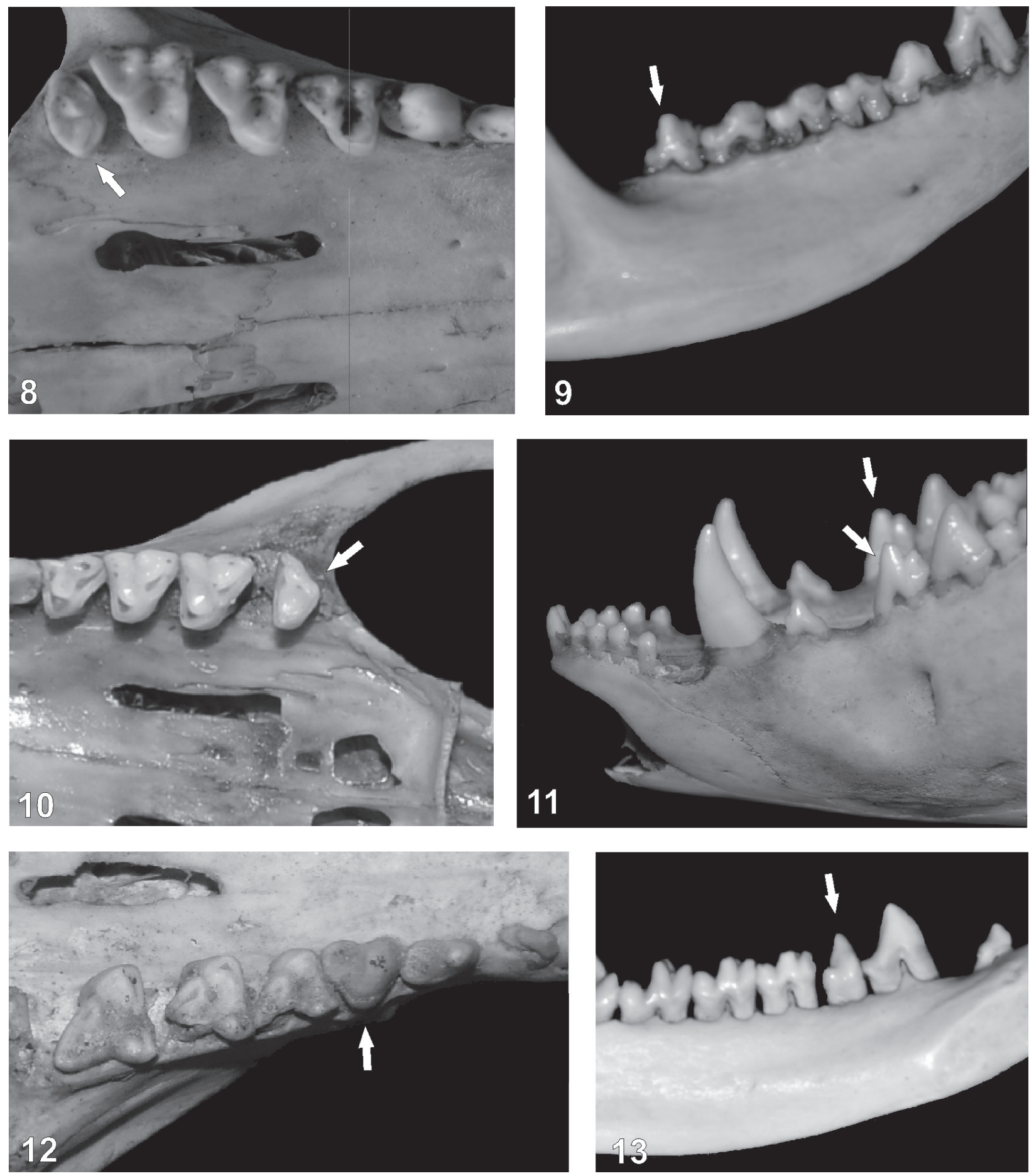

Figs 8-13. Dental anomalies in Didelphis albiventris Lund, 1840: 8, ZVC 1285; 9, CFA 2663; 10, CFA 10249; 11, MACN 24168; 12, MACN 32.184; 13, MACN 36.734. White arrows indicate the anomaly. See text for details.

MACN 32.184 has a three-rooted left $\mathrm{P}^{3}$; MACN 36.734 has a right $\mathrm{P}_{3}$ with fused roots; and CNP s.n. has a single-rooted, peg-like left $\mathrm{P}_{1}$; Figs. 12, 13).

Teeth in unusual positions were not common in Didelphis albiventris $(\mathrm{n}=5,13 \%)$, which were found in two molars, two premolars and one incisor (Tab. II). Specimen MZUSP 16536 shows both $\mathrm{M}_{4}$ lingually oriented (i.e., transverse to the main mandibular axis). Specimen MZUSP 2996 has an anteriorly oriented right $\mathrm{M}^{3}$, with the molar's crown overlapping $\mathrm{M}^{2}$ and $\mathrm{M}^{4}$ (Fig. 14). Specimen AMNH 41536 has a lingually oriented left $\mathrm{P}^{3}$, while specimen MNHN 3963 has a lingually oriented left $\mathrm{P}_{3}$ (Fig. 15). In specimen MACN 24163, the left $I_{3}$ has grown with a lingual orientation, thus blocking the eruption of $\mathrm{I}_{2}$ (Fig. 16).

In our limited access to specimens of $D$. marsupialis and D. aurita from Brazil, we found three specimens (4.61\%) with anomalies in the former, and two $(2.1 \%)$ in the latter. In D. marsupialis, specimen MZUSP 10593 has a fourth 

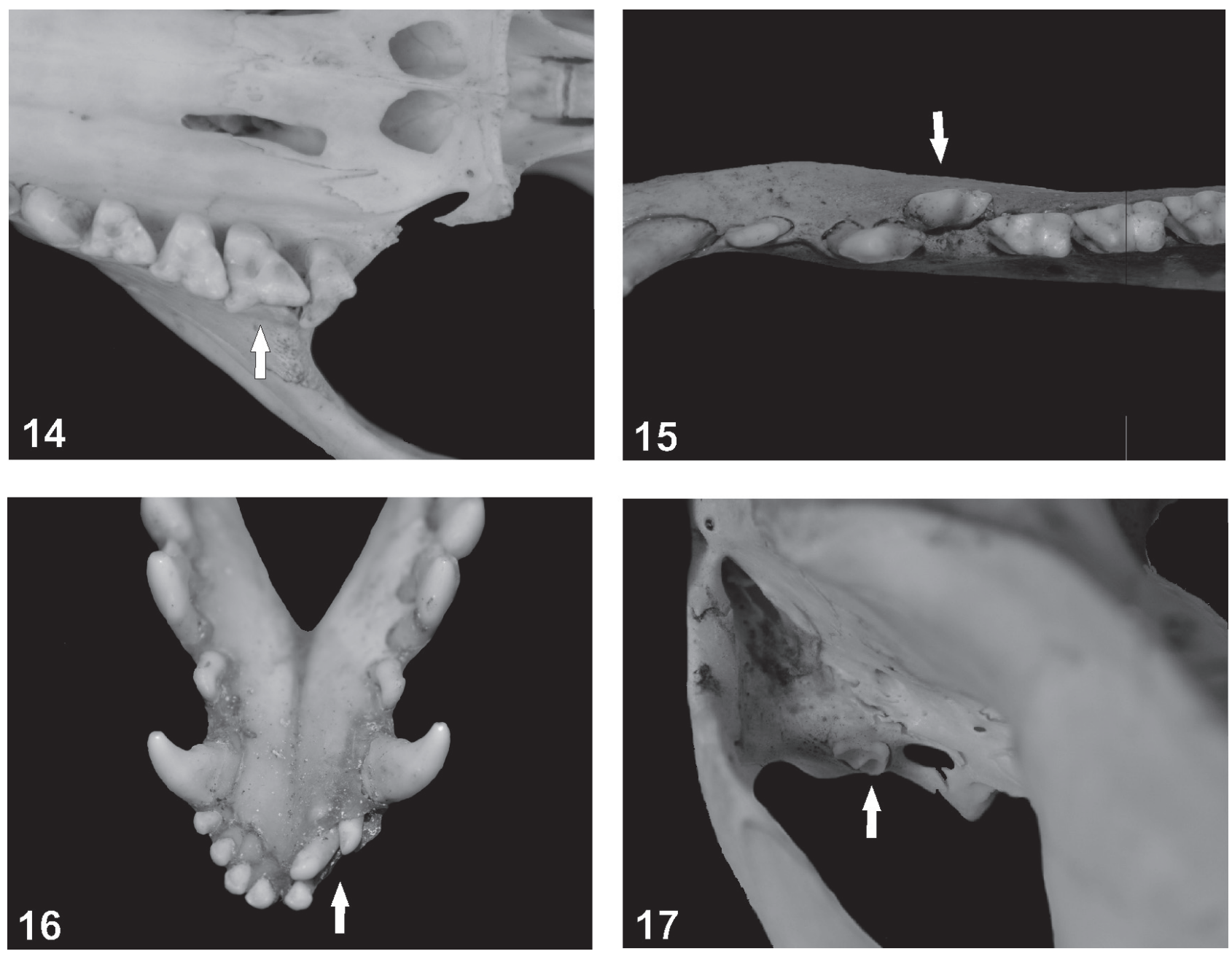

Figs 14-17. Dental anomalies in Didelphis albiventris Lund, 1840 and D. marsupialis Linnaeus, 1758: 14, MZUSP 2996; 15, MNHN 3963; 16, MACN $24163 ; 17$, MZUSP 4745 . White arrows indicate the anomaly. See text for details.

premolar instead of the right $\mathrm{M}_{1}$; specimen MZUSP 17242 has a third alveolus with a root in the right $\mathrm{M}_{1}$, but since the crown is broken, it is hard to tell whether it is a threerooted molar or a peg-like supernumerary molar; specimen MZUSP 4745 has a multi-cuspidate molar behind the right $\mathrm{M}^{4}$, growing towards the dorsal side of the palatine, posterior to the interpterigoid bridge (Fig. 17). In D. aurita, specimen NMW 2646 has a missing left $\mathrm{P}_{1}$; specimen NMW 1658 has a left $\mathrm{P}_{1}$ with fused roots.

\section{DISCUSSION}

The percentage of specimens with anomalies found for $D$. albiventris is higher than those previously reported for the species [0.3\% in Astúa DE MoRAEs et al. (2001), and $0.9 \%$ in GonZÁLEZ (2000)]. This is probably due to the fact that previous studies only refer to supernumerary molars, excluding other types of anomalies which we analyzed herein. MiLes \& GRIGSON (1990) reported a larger percentage of specimens with anomalies, but since they described their results separated by genera and not by species, it is hard to infer the actual number of anomalies for $D$. albiventris.
The authors mentioned $7.3 \%$ of specimens with variations in number, size and shape, and $10.7 \%$ of specimens with variations in position for the genus Didelphis. In our comparison with specimens of $D$. marsupialis $(\mathrm{n}=74)$ and D. aurita $(\mathrm{n}=96)$, we found a higher percentage of anomalies in D. albiventris.

In other species of Didelphimorphia, lower percentages of anomalies have been reported (between $0.3 \%$ and $2.8 \%$, Astúa DE Moraes et al., 2001), and even no specimens with anomalies were found in Thylamys spp. and Lestodelphys halli (Thomas, 1921) (MARTIN, 2007).

ARCHER (1975) described different percentages of anomalies for several species of the Australian Order Dasyuromorphia, ranging from $3 \%$ to $25.5 \%$. Most of the species showed between $3 \%$ and $14 \%$ of specimens with anomalies, and only Sarcophilus harrisii (Boitard, 1841) and Planigale maculata (Gould, 1851) reached higher values (17.5\% and $25.5 \%$ respectively). MARTIN $(2007,2013)$ reported high percentages of specimens with anomalies for Dromiciops gliroides Thomas, 1894 (Order Microbiotheria), Caenolestes fuliginosus Tomes, 1863, Lestoros inca (Thomas, 1917) and Rhyncholestes raphanurus Osgood, 1921 (Order 
Paucituberculata), ranging from $8.8 \%$ in D. gliroides to $15 \%$ in C. fuliginosus, and $30 \%$ in L. inca and $R$. raphanurus. Most of the anomalies described for those species have no functional value, since they are located in places where they do not "disturb" occlusion, nor they interfere with the animals' holding of the prey capacity, and consequently there is no (or very little) selective pressure to eliminate them from the population (MARTIN, 2007). Inbreeding and limited gene flow were the possible causes suggested by MARTIN $(2007,2013)$ to explain the high number of anomalies found in $C$. fuliginosus, L. inca and $R$. raphanurus, since these species inhabit insularized areas, which experienced climatic changes in the past, and are under different levels of antropogenic disturbances. On the other hand, the number of anomalies found for D. gliroides, much smaller than the percentages described for Caenolestids, was explained using the divergence time between both marsupial lineages $(\sim 10$ million years) and the different ecological requirements of D. gliroides (MARTIN, 2007). In the case of D. albiventris, inbreeding and limited gene flow do not appear as possible explanations to the elevated percentage of anomalies, especially due to its ecological characteristics (i.e., the species is widely distributed and occupies a broad array of habitats and/or ecosystems). Different studies have shown D. albiventris has a wide home range, estimated in ca. 1100 $\mathrm{m}^{2}$ (daily home range) in an urban forest fragment using a spool-and-line technique (AlmeIDA et al., 2008), 2.33 \pm 2.32 ha in an island, and 0.68 ha in an urban forest, calculated using a capture and recapture method (SANCHES et al., 2012). Individuals of both sexes expand their home range during the reproductive season (CÁCERES et al., 2012). However, home range alone is not sufficient, since similar ranges were estimated for Dromiciops gliroides in Chile (FONTúrBEL et al., 2010), despite clear differences in body mass (i.e., $D$. albiventris weighs 0.5 to $2.5 \mathrm{~kg}$; D. gliroides weighs 16 to 32 g; Astúa de Moraes, 2015; PAlma \& VAlladares-Gómez, 2015). An important characteristic of the spatial ecology of $D$. albiventris is its ability to move between isolated fragments of forest or other unsuitable habitats, allowing genetic flow between populations and avoiding isolation (Fernandez \& Pires, 2006), while D. gliroides has a limited dispersal between forest patches (FONTÚRBEL et al., 2010). Moreover, $D$. albiventris is able to live in highly modified environments such as urban and rural areas, where it exploits human settlements for food resources, being capable to adapt to unstable environments (SMith, 2007; CostA et al., 2015). Consequently, it is difficult to consider that a species with such broad ecological characteristics is exposed to inbreeding or limited gene flow.

As mentioned above, the habitat used by this species tends to be unstable, and this instability, added to the exposure to chemicals in dumpers in cities and densely urban areas, are environmental stressors, which are linked to developmental instability and fluctuating asymmetry (LEAMY \& KLINGenberG, 2005). Most of the dental anomalies we describe in this work can be interpreted as cases of fluctuating asymmetry, since they are present in only one side of the dental toothrow (81\% of asymmetrical anomalies, see Tab. II). Moreover, developmental instability and fluctuating asymmetry have already been used as an explanation for dental anomalies in canids (PALMQVist et al., 1999), and in otters (HAUER, 2002). Ongoing morphometric analyses to determine the level of fluctuating asymmetry will help establish the influence of environmental stressors in this species, and consequently find support for this hypothesis.

The difference in percentage of anomalies between $D$. albiventris and the other Didelphis species analyzed herein (D. aurita and D. marsupialis) could also be explained by environmental instability. In general, Didelphis albiventris inhabits an unstable environment when compared with the other two species, which includes semi-arid regions of Brazil, and temperate areas of Argentina (GENTILE et al., 2012). The hypothesis that environmental instability induces, or has an influence in the prevalence of, dental anomalies in D. albiventris, can be supported by comparing samples from different habitats. If we only analyze the sample of D. albiventris from Brazil (which is mostly from forested habitats of the Mata Atlântica; Fig. 1), percentages for the three species of Didelphis become similar (see table I). In contrast, specimens from Argentina and Uruguay have almost 3.5 times more anomalies. Therefore, different factors influencing the dental development of opossums in Argentina and Uruguay on one side, and Brazil in the other, could provide a possible explanation to the patterns described herein.

From a functional point of view, it is noteworthy that most of the anomalies we described for D. albiventris, and those found in D. aurita and D. marsupialis, are predominantly located at the end of the toothrow, with only a few specimens showing anomalies in premolars, canines and incisors. This has a direct correlation with the masticatory cycles observed in Didelphis spp., in which incisors and canines have a function acquiring food during ingestion, premolars and molars in puncturing items (the puncturecrushing process described by HiIEMAE \& CROMPTON, 1971), which are later passed on to the molars for mastication (the cutting and shearing stroke; see also Turnbull, 1970; Crompton \& Hitemae, 1970). Dental anomalies in places other than the end of the toothrow would imply malocclusion, reducing effectiveness during chewing cycles and producing an unbalanced power stroke. As proposed by MARTIN (2007), dental anomalies could be found more predominantly, in areas of the toothrow where occlusion is relaxed or does not prevent teeth from interlocking during mastication.

Further work using morphometric analyses in different populations of $D$. albviventris, D. aurita and D. marsupialis, could shed some light on the hypothesis we presented herein.

Acknowledgments. We wish to thank the curators of the following collections for allowing the study of materials under their care: D. Flores, S. Lucero and P. Teta (MACN); S. Bogan (CFA); I. Olivares (MLP-Ma); A. Pautasso (MSF); U. Pardiñas (CNP); E. Gonzalez (MNHN); R. Maneyro (ZVC); M. de Vivo and J. Gualda (MZUSP); R. Voss (AMNH); 
F. Zachos (NMW). G.M. Martin thanks E. Watkins and M. Simeon for their economic support. This is a contribution to PICT 2012-0256 by the Agencia Nacional de Promoción Científica y Tecnológica.

\section{REFERENCES}

Almeida, A. J.; Torquetti, C. G. \& Talamoni, S. A. 2008. Use of space by Neotropical marsupial Didelphis albiventris (Didelphimorphia) in an urban forest fragment. Revista Brasileira de Zoologia 25:214-219.

ARCHER, M. 1975. Abnormal dental development and its significance in dasyurids and other marsupials. Memoirs of the Queensland Museum 17:251-265.

Astúa de Moraes, D. 2015. Order Didelphimorphia. In: WiLson, D. E. \& Mittermeier, R. A. eds. Handbook of the Mammals of the World. Vol. 5. Monotremes and Marsupials. Barcelona, Lynx Editions, p.69-186.

Astúa de Moraes, D.; Lemos, B. \& Cerqueira, R. 2001. Supernumerary molars in neotropical opossums (Didelphimorphia, Didelphidae). Mammalian Biology 66:193-203.

Cáceres, N. C.; Prevedello, J. A. \& Loretto, D. 2012. Uso do espaço por marsupiais: fatores influentes sobre área de vida, seleção de habitat e movimentos. In: CÁCERES, N. C. ed. Os marsupiais do Brasil: biologia, ecologia e conservação. Campo Grande, Editora UFMS, p.325-344.

Carrera, M. \& Udrizar Sauthier, D. E. 2014. Enlarging the knowledge on Didelphis albiventris (Didelphimorphia, Didelphidae) in northwestern Patagonia: New records and distribution extention. Historia Natural 4:111-115.

Cerqueira, R. \& Tribe, C. J. 2008. Genus Didelphis Linnaeus, 1758. In: Gardner, A. L. ed. Mammals of South America, Volume 1. Marsupials, Xenarthrans, Shrews, and Bats. Chicago, The University of Chicago Press, p.17-25.

Chemisquy, M. A.; Prevosti, F. J; Martin, G. \& Flores, D. A. 2015. Evolution of molar shape in didelphid marsupials (Marsupialia: Didelphidae): analysis of the influence of ecological factors and phylogenetic legacy. Zoological Journal of the Linnean Society 173:217-235.

Costa, L. P.; Astúa de Moraes, D.; Brito, D.; Soriano, P. \& Lew, D. 2015. Didelphis albiventris. The IUCN Red List of Threatened Species 2015: e.T40489A22176404. Available at $<$ http://dx.doi.org/10.2305/ IUCN.UK.2015-4.RLTS.T40489A22176404.en.>. Accessed on 15 March 2016

Crompton, A. W. \& HiIemae, K. M. 1970. Molar occlusion and mandibular movements during occlusion in the American opossum, Didelphis marsupialis L. Zoological Journal of the Linnean Society 49:21-47.

Drehmer, C. J.; Sanfelice, D. \& Loch, C. 2015. Dental anomalies in pinnipeds (Carnivora: Otariidae and Phocidae): occurrence and evolutionary implications. Zoomorphology 134:325-338.

Fernandez, F. A. S. \& Pires, A. S. 2006. Perspectivas para a sobrevivência dos marsupiais brasileros em fragmentos florestais: o que sabemos e o que ainda precisamos aprender? In: CÁCERES, N. C. \& MONTEIRo FILHO, E. L. A. eds. Os marsupiais do Brasil. Biologia, Ecologia e Evolução. Campo Grande, Editora UFMS, p.191-202.

Flores, D. A. 2006. Orden Didelphimorphia. In: Barquez, R. M.; DíAZ, M. M. \& Ojeda, R. A. eds. Mamíferos de Argentina. Sistemática y Distribución. Mendoza, Sociedad Argentina para el Estudio de los Mamíferos, p. 18-22.

FontúRbel, F. E.; Silva-RodríGuez, E. A.; CÁRDENAS, N. H. \& JimÉnez, J. E. 2010. Spatial ecology of monito del monte (Dromiciops gliroides) in a fragmented landscape of southern Chile. Mammalian Biology 75:1-9.

Gentile, R.; Teixeira, B. R. \& Bergallo, H. G. 2012. Dinâmica populacional de marsupiais brasileiros. In: CÁCERES, N. C. ed. Os marsupiais do Brasil: biologia, ecologia e conservação. Campo Grande, Editora UFMS, p.309-324.

GonZÁLEZ, E. M. 2000. Molares supernumerarios en Didelphis albiventris Lund, 1841 (Mammalia, Didelphimorphia, Didelphidae). Boletín de la Sociedad Zoológica de Uruguay (segunda época) 12:41-43.

GonzÁlez-Ruiz, L. R.; Ciancio, M. R.; Martin, G. M. \& Zurita A. E. 2015. First record of supernumerary teeth in Glyptodontidae (Mammalia,
Xenarthra, Cingulata). Journal of Vertebrate Paleontology 35(1): e885033 doi:http://dx.doi.org/10.1080/02724634.2014.885033

HaUer, S. 2002. Population analysis of dental anomalies of otters Lutra lutra from eastern Germany. Acta Theriologica 47:339-362.

HiIEmae, K. M. \& Crompton, A. W. 1971. A Cinefluorographic study of feeding in the American opossum, Didelphis marsupialis. In: DAHLBERG, A. A. ed. Dental Morphology and Evolution. Chicago, Chicago University Press, p.299-334.

Leamy, L. J. \& Klingenderg, C. P. 2005. The genetics and evolution of fluctuating asymmetry. Annual Review of Ecology, Evolution, and Systematics 36:1-21.

LeE, A. K. \& COCKBURn, A. 1987. Evolutionary Ecology of Marsupials. Monographs on Marsupial Biology. Cambridge, Cambridge University Press. 284p.

Martin, G. M. 2007. Dental anomalies in Dromiciops gliroides (Microbiotheria, Microbiotheriidae), Caenolestes fuliginosus and Rhyncholestes raphanurus (Paucituberculata, Caenolestidae). Revista Chilena de Historia Natural 80:393-406.

Martin, G. M. 2013. Intraspecific variability in Lestoros inca (Paucituberculata, Caenolestidae), with reports on dental anomalies and eruption pattern. Journal of Mammalogy 94:601-617.

Massoia, E. \& Lartigau, B. 1995. Mamíferos (Rodentia, Lagomorpha y Marsupicarnivora) cazados por Tyto alba en el río Limay, departamento Pilcaniyeu, provincia de Río Negro. Boletín Científico Asociación Protección Naturaleza 27:15-18.

MASSOIA, E.; ForASIEPI, A. \& TETA, P. 2000. Los Marsupiales de Argentina. Buenos Aires, L.O.L.A. (Literature of Latin America). 71p.

MCAfEe, R. K. 2015. Dental anomalies within extant members of the mammalian Order Pilosa. Acta Zoologica 96:301-311.

Miles, A. E. W. \& Grigson, C. 1990. Colyer's variations and diseases of the teeth of animals. Cambridge, Cambridge University Press. 688p.

Palma, R. E. \& Valladares-Gómez, A. 2015. Order Microbiotheria. In: WiLSON, D.E. \& MitTermeier, R. A. eds. Handbook of the Mammals of the World. Vol. 5. Monotremes and Marsupials. Barcelona, Lynx Editions, p.199-208.

PalmQVist, P.; Arribas, A. \& NaVARro-MartíneZ, B. 1999. Ecomorphological study of large canids from the lower Pleistocene of southeastern Spain. Lethaia 32:75-88.

Reig, O. A.; Kirsch, J.A.W. \& Marshall, L. G. 1987. Systematic relationships of the living and neocenozoic American 'opossumlike' marsupials (suborder Didelphimorphia), with comments on the classification of these and the Cretaceous and Paleogene New World and European Metatherians. In: ARCHER, M. ed. Possums and opossums: studies in evolution. Chipping Norton, Surrey Beatty and the Royal Zoological Society of New South Wales, p.1-89.

Sanches, V. Q. A.; Gomes, M. M. A.; Passos, F. C.; Graciolli, G. \& Ribas A. C. A. 2012. Home-range and space use by Didelphis albiventris (Lund 1840) (Marsupialia, Didelphidae) in Mutum Island, Paraná River, Brazil. Biota Neotropica 12(4) Available at $<$ http://www.biotaneotropica.org. br/v12n4/en/abstract?article+bn00612042012>

Sмith, P. 2007. FAUNA Paraguay Handbook of the Mammals of Paraguay, Volume 1: Marsupialia: Didelphis albiventris p. 26-34. Available at http://www.faunaparaguay.com. Accessed on 14 April 2016.

TuRnBull, W. D. 1970. Mammalian masticatory apparatus. Fieldiana Geology 18:149-356.

Tyndale-Biscoe, C. H. \& MacKenzie, R. B. 1976. Reproduction in Didelphis marsupialis and Didelphis albiventris in Colombia. Journal of Mammalogy 57:249-265.

Ungar, P. S. 2010. Mammal teeth: origin, evolution, and diversity. Baltimore, Johns Hopkins University Press. 304p.

Vieira, E. M. \& Astúa de Moraes, D. 2003. Carnivory and insectivory in Neotropical marsupials. In: Jones, M; Dickman, C. \& ArCher, M. eds. Predators with pouches: the biology of carnivorous marsupials. Collingwood, CSIRO Publishing, p. 271-284.

Wolsan, M. 1984. The origin of extra teeth in mammals. Acta Theriologica 29:128-133. 
Appendix 1. Collection number and geographical origin of the specimens with dental anomalies.

Didelphis albiventris. BRAZIL: Pernambuco, Fazenda Batente (MZUSP 16536); Goiás (AMNH 132949; AMNH 132951); Mato Grosso do Sul, Maracajú (AMNH 132983; AMNH 132984); São Paulo, Ituverava (MZUSP 2996). ARGENTINA: Salta (AMNH 41536); Salta, Anta, El Quebrachal (MACN 36.734; MACN 36.753); Formosa, Pirané, El Colorado (CFA 3235); Misiones, Candelaria, Arroyo Viña (CFA 4510); Misiones, Capital, Ruta 12, Arroyo Itaembé (CFA 6041); Corrientes, Capital, Barrio Lomas (MACN 24163; MACN 24168; MACN 24174); Santiago del Estero, Guasayán, Estancia Guampacha (CFA 10249); La Rioja, Castro Barros, Anillaco (CRILAR-Ma 66); Entre Ríos, Concordia, Nueva Escocia, Estancia La Lisa (MACN 49.49); Entre Ríos, Villaguay, Colonia Berro (CNP s.n.); Buenos Aires, Ensenada, Punta Lara (CFA 2663); Buenos Aires, Chascomús (MACN 25.23); without location (MACN 32.184). URUGUAY: Tacuarembó, Río Negro y Río Tacuarembó (MNHN 2544); Soriano, Routes 105 and 21(ZVC 1285); Río Negro, Fray Bentos, M’Bopicuá (MNHN 2590); San José, Cerro Zarco (MNHN 3964); Montevideo, Prado (MNHN 3394); Montevideo, Facultad de Agronomía (MNHN 3961); Montevideo, Jardín Botánico (MNHN 3963); without location (ZVC 1167).

Didelphis marsupialis. BRAZIL: Amazonas, Itacoatiara, Lago de Serpa (MZUSP 4745); Pará, Cametá (MZUSP 10593); Pará, Rodovia Belém-Brasília Km 87-94 (MZUSP 17242).

Didelphis aurita. BRAZIL: Santa Catarina, Joinville (NMW 2646); Santa Catarina, Theresópolis (NMW 1658). 